\title{
INNOVATIVENESS OF BELARUSIAN ECONOMY THROUGH THE PRISM OF ITS COMPETITIVE POSITION IN INTERNATIONAL TRADE
}

\author{
Krzysztof Falkowski ${ }^{1}$
}

\begin{abstract}
The main purpose of this study is to answer the question of how innovative Belarusian economy is. Its innovativeness has been assessed through an in-depth analysis of Belarus' position in international trade, especially in highand medium-high-technology goods, on the back of the assumption that any competitive advantages possessed in them testify to the economy's high innovativeness. The analysis of the dynamics of long-term revealed comparative advantages in Belarusian foreign trade by using Balassa's RCA methodology and covering the years 2000-2014, has shown that the country was generally characterized by low innovativeness, as evidenced by the possession of such advantages only in trade in goods of relatively low technological intensity (medium-low technology). Meanwhile, in hi-tech goods (high and medium-high technology), Belarus did not have any (or only had relatively small) long-term revealed comparative advantages. Moreover, Belarus' competitiveness in international trade deteriorated over that period, not only regarding high and medium-high technology goods but also in foreign trade overall. This seems to be, amongst others, the consequence of low efficiency of the country's current innovation policy.
\end{abstract}

JEL Classification Numbers: F14, O31, P45; DOI: http://dx.doi.org/10.12955/cbup.v5.912

Keywords: innovativeness, competitiveness, comparative advantages, international trade, Belarus

\section{Introduction}

In the contemporary time, amidst the advancement of globalization and internationalization of business activities on a global scale, it is becoming increasingly difficult to meet the growing competition in the international markets for goods and factors of production, which is one of the important reasons for the strong diversification of economic growth and development of individual countries in the twenty-first century (Hämäläinen, 2003). Experiences of many countries around the world, being a kind of empirical exemplification of a number of different theoretical concepts, indicate that today the most important factors of international competitiveness, as well as of the aforementioned economic growth, are - apart from wider institutional factors - human capital and essential innovations/innovativeness of the economy (Aghion \& Howitt, 1992; Arrow, 1962; Atkinson \& Ezell, 2012; Drucker, 1992; Lucas, 1988; Lundval, 1992; Romer, 1989).

For these reasons, it seems worthwhile to take a closer look at the competitiveness of Belarusian economy, being a consequence of its level of innovativeness, to answer the question how this largest European country without access to the sea, strongly associated with Russia and the post-Soviet economic area, manages to cope in an era of ever-fiercer international competition increasingly based on knowledge, modern technologies, and innovations. Another important reason for analyzing this issue is a striking shortage of research papers concerning Belarus and its economy in international economic literature, including also those covering research on the innovativeness and competitiveness of Belarusian economy.

In this article, an attempt has been made to assess the innovativeness of Belarus through the prism of the competitiveness of its economy in international trade, especially in technologically advanced goods. It is based on the core assumption that the possession of any long-term comparative advantages in international trade in the field of hi-tech goods (i.e. the goods of high and medium-high technology) directly testifies to the high innovativeness of the whole economy. Moreover, the strengthening of the existing comparative advantages or acquiring new ones with respect to these hi-tech goods, over time, is by definition evidence of effective innovation policy pursued by the country. To assess the level of Belarusian economy's competitiveness, the method of analyzing revealed comparative advantages developed by B. Balassa is applied.

Based on the results of the analysis above, this study puts forth the thesis according to which, in the case of Belarus, the absence of any (or only relatively small) long-term competitive advantages in international trade in hi-tech goods demonstrates the low innovativeness of this country's economy. Also, the low effectiveness of its innovation policy can be considered, which is particularly disadvantageous for its further economic growth and development.

\footnotetext{
${ }^{1}$ Warsaw School of Economics, Poland, kfalkow@sgh.waw.pl
} 


\section{Literature review}

The state of research on the innovation of Belarusian economy and its competitiveness in the contemporary international trade, published in English and available to all those interested in this issue around the world, still leaves a lot to be desired. Regrettably, an almost complete lack of this kind of research papers and publications can be observed, even though both the country itself, as well as this issue, not only from an economic point of view, seem to be very relevant and exciting. A significant barrier to such research, especially the one survey-based one, is undoubtedly the availability and reliability of the necessary data. Also for this reason, amongst others, Belarus is not included in the most widely-known and popular publication concerning competitiveness, The Global Competitiveness Report, prepared annually by the World Economic Forum (Schwab, 2016).

About the competitiveness of Belarus, which is no doubt a direct consequence of its innovativeness, Dobrinsky et al. (2016) state that the two categories of goods in which Belarusian industry is most competitive globally are agricultural and food products, and chemicals. They go on to observe that although under the Eurasian Economic Union (EAEU) framework protectionist measures have been imposed and state interventions have been undertaken to support high value added sectors, the competitiveness of the relatively more advanced sectors has been in decline over the last decade. Thus, Belarus can serve as a counter-argument to the 'infant industry' argument, also as it is part of the EAEU which comprises countries facing similar development problems stemming from the insufficient modernization of their industries, as well as from weak infrastructure and institutions.

What's more, Freinkman, Bakanova, and Sidarenka (2010) also note that Belarus' comparative advantages have steadily weakened over the last several years. Based on the estimates of revealed comparative advantages (RCA), they observe that the country's comparative advantages have changed from labour- and capital-intensive goods to natural resources and petroleum, which puts limits on creating jobs and improving productivity. Moreover, what has hardly changed is the so-called "export sophistication," a feature of more developed countries which can export a wide variety of higher value goods. This would indicate, amongst others, that the shift has been towards goods with lower technological content. Alarmingly, Belarus also seems to be losing its share in markets with higher export sophistication (such as Russia). Similar conclusions were also reached by Falkowski (2013, 2016). Also, as noted by Dabrowski (2016), Belarusian enterprises are increasingly losing their competitiveness on the traditionally significant markets of Russia and other CIS countries. This, in turn, largely explains the gradually deteriorating overall competitive position of Belarus on international commodity markets (Havlik, Astrová, \& Pindyuk, 2012).

The major challenges facing Belarusian economy, also in the context of the actual relatively low international competitiveness being a consequence of its relatively low innovativeness, are described by i.a. Bikar and Kmet'ko (2015), Egorov (2014), Shirov, Sabchishina and Potapenko (2016).

\section{Research methodology and data}

In the literature, a multitude of different methods for assessing the international competitiveness of economies is in use, both from their capacities as well as their innovation position. One of the methods of assessing innovativeness in an economy is to analyze the structure of its foreign trade, especially in goods of high technological intensity. It is also one of the methods applied to assess the innovativeness of economies in "Innovation Union Scoreboard" reports, commissioned by the European Commission. Among indicators used by authors of these reports are the shares of high-technology and mediumtechnology goods as well as of knowledge-based services in the export of the country (The European Union, 2014). A similar methodology of measuring innovativeness is also applied by creators of Global Innovation Index reports (Dutta, Lanvin, \& Wunsch-Vincent, 2015).

In this study, however, to conduct an in-depth analysis of the innovativeness of Belarusian economy, the method of analyzing revealed comparative advantages (RCA) in international trade developed by Balassa $(1965,1989)$ has been applied; specifically, the study uses Balassa's original logarithmic formula of:

$$
R C A_{i}=\ln \left(\frac{X_{i j}}{X_{j}} \div \frac{X_{i}}{X}\right)
$$

where: 
$R C A_{i}$ - the revealed comparative advantages index of the given country in the $i$ goods category $X_{i j}$ - exports of the $i$ goods category from the given country to the $j$ country or category of $j$ countries $X_{j}$ - total exports from the given country to the $j$ country or category of $j$ countries

$X_{i}-$ global total exports of the $i$ goods category

$X$ - global total exports

The logarithmic form of the formula ensures the symmetry of both positive and negative values of the $\mathrm{RCA}_{\mathrm{i}}$ index in the region around 0, which facilitates their interpretation (Vollrath, 1991). If $\mathrm{RCA}_{\mathrm{i}}>0$, then the country enjoys a revealed comparative advantage in trading goods from the given category and the value of the index indicates the degree of such an advantage. On the contrary, if $\mathrm{RCA}_{\mathrm{i}}<0$, then no such revealed comparative advantage, to a higher or lower degree, exists.

In order to identify potential long-term comparative advantages in foreign trade of Belarus, especially in the field of hi-tech goods (i.e. the goods of high and medium-high technology), as it is their occurrence and intensity which should be regarded as a kind of acid test for innovativeness of the economy, the entire commodity structure of foreign trade of Belarus in the years 2000-2014 is analysed herein below. Also, the analyzed goods have been broken down into four basic categories according to the OECD classification based on their technology intensity, namely into the goods of high, medium-high, medium-low and low technology (Hatzichronoglou, 1997; Organization for Economic Co-operation and Development, 2011). Such methodological approach makes it possible to formulate certain conclusions about the innovativeness of Belarusian economy in the contemporary global economy. All data used for the analysis are derived from the United Nations Commodity Trade Statistics Database.

\section{Empirical research results}

When analyzing the development of long-term revealed comparative advantages (RCA) in the foreign trade of Belarus in the years 2000-2014, taking into account the aforementioned OECD classification of goods based on their technological intensity, it must first be very clearly emphasized that throughout the analyzed period the country had the greatest comparative advantages in trade in the medium-low technology category (see Figure 1). However, what can be noted is that starting from 2009 on these benefits began to diminish. On the other hand, in the case of the low- and medium-hightechnology categories, Belarus had certain, admittedly relatively low, but still present, comparative advantages throughout the entire analyzed period. However, in the last two years covered by the analysis, that is 2013-2014, a gradual deterioration became noticeable about the medium-hightechnology category, leading to the loss of these advantages.

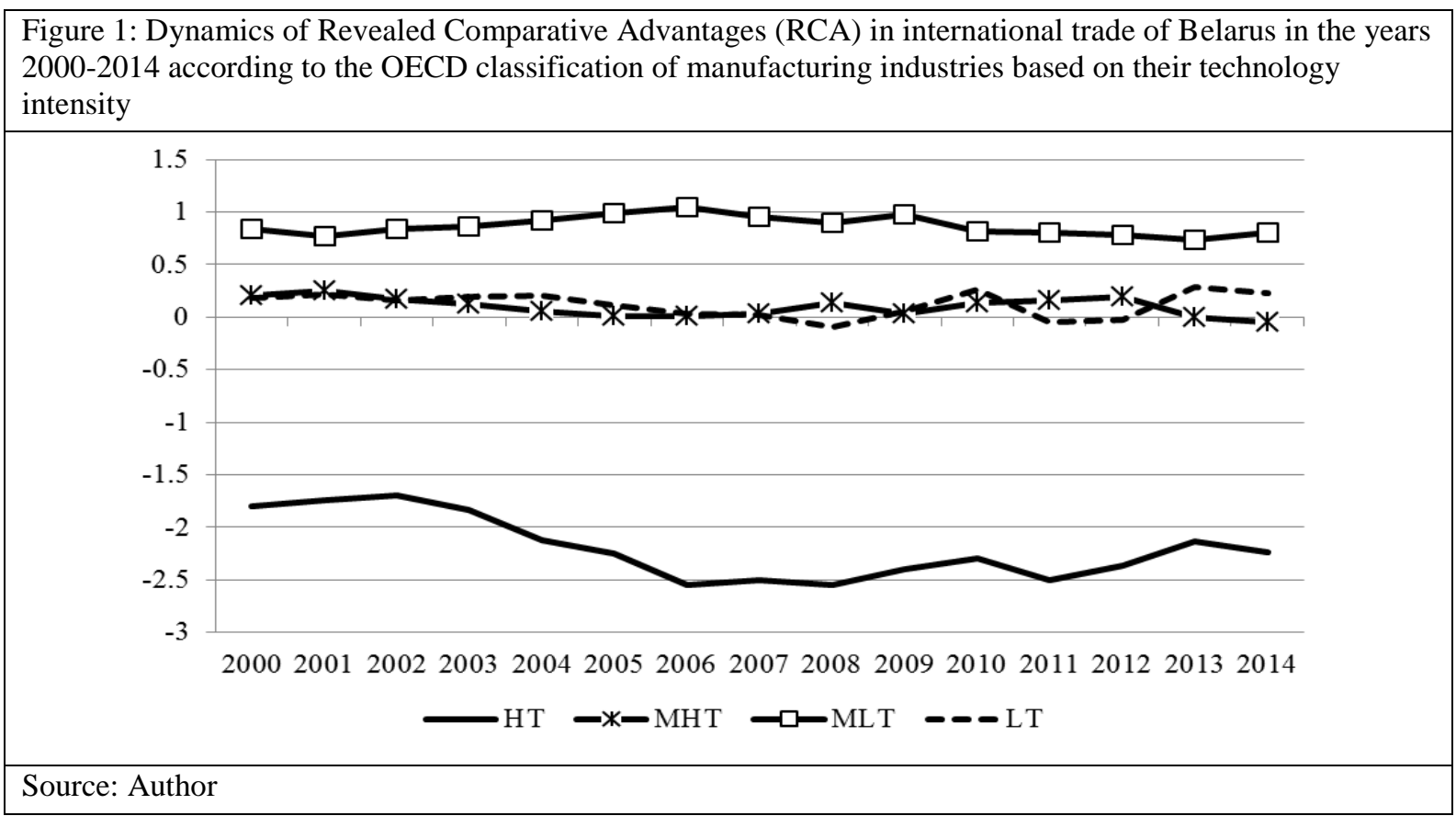


On the other hand, concerning the hi-tech goods, especially significant from innovativeness of any economy, as they come from industries intensively using common factors of production and characterized by a high level of innovation, the situation in Belarus has for years been dramatic. Not only did Belarus not have any comparative advantages in the period 2000-2014 years in this category, but the competitiveness of Belarusian goods from this category in total has deteriorated.

Secondly, because, as indicated above, particular attention in the context of innovation of Belarusian economy should be paid to its competitiveness regarding two categories, i.e., the high- and mediumhigh-technology categories. Figure 2 shows the dynamics of RCA indices for Belarus in these two categories in the years 2000-2014.

According to the OECD classification, the category of high-technology goods includes the following five subcategories of goods: aircraft and spacecraft; medical, precision and optical instruments; office, accounting, and computing machinery; pharmaceuticals; radio, TV, and communications equipment.

The analysis of the data presented in Figure 2, concerning the competitiveness of Belarusian economy in the international trade and individual subcategories of goods within the high-technology category according to the OECD classification, in the years 2000-2014, has revealed that Belarus did not have any comparative advantage (RCA values < 0) in any of them. By far the most uncompetitive in the international arena was Belarus traditionally in the aircraft and spacecraft subcategory (the lowest values of RCA recorded throughout the entire analyzed period, with a negative trend).

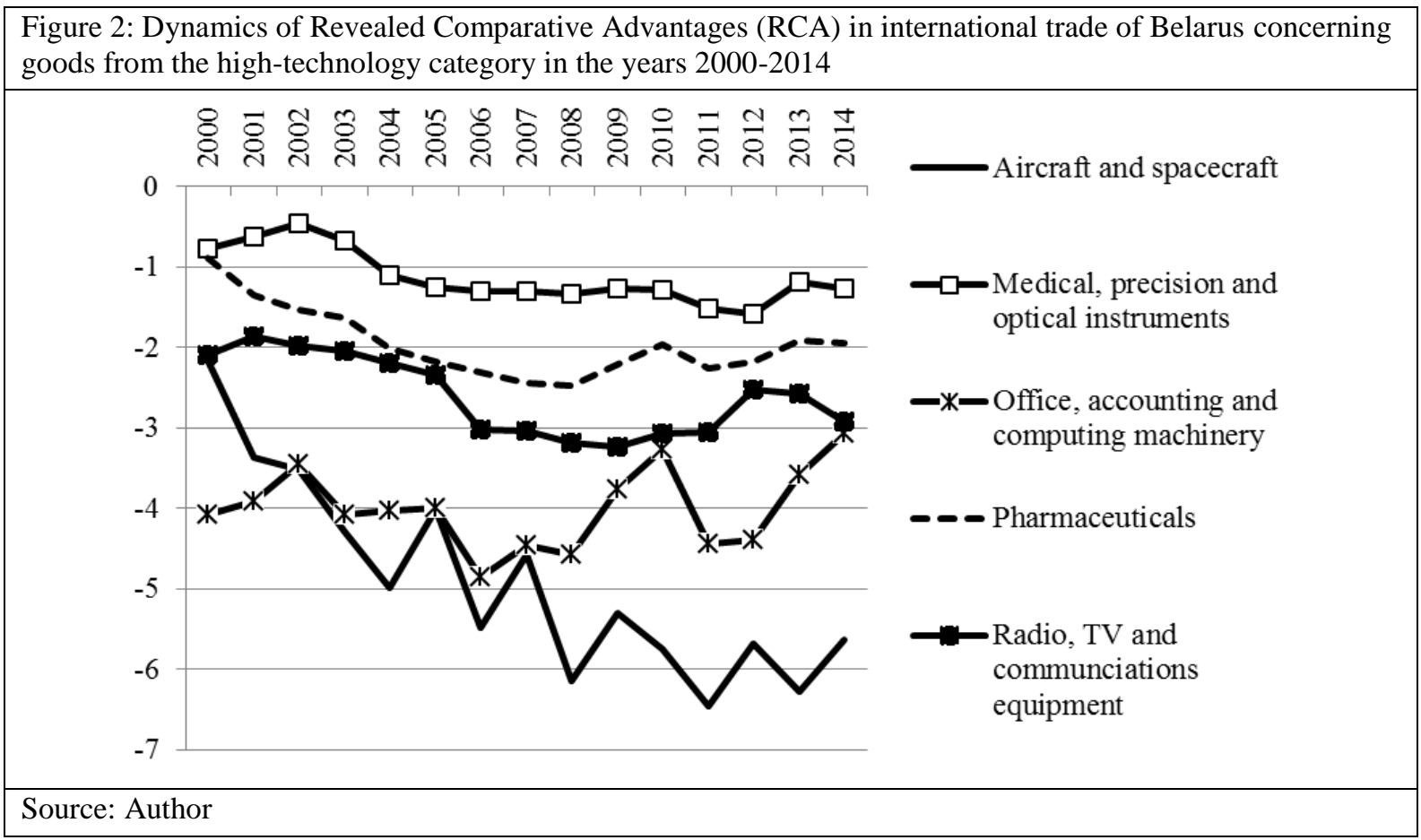

Among all subcategories of goods within the high-technology category, regarding its international competitiveness, as measured by the RCA index, Belarus fares relatively the best in the medical, precision and optical instruments subcategory. However, even for this subcategory overall, the RCA is negative, which indicates that Belarusian economy does not have any comparative advantages in international trade in this subcategory either. Nevertheless, the relatively best situation in respect of the remaining subcategories is the consequence of the fact that if we look deeper into the structure of Belarusian goods trade at the level of individual, specific categories of goods, and specific values of the RCA index, it turns out that it is in this very subcategory, i.e., medical, precision and optical instruments, that Belarus has the highest comparative advantages out of all hi-tech goods (Table 1). It is, therefore, a kind of Belarusian export specialization.

The second category of goods, which from the point of view of the innovativeness of Belarusian economy should be assessed, is the category of medium-high-technology goods, according to the OECD classification which includes the following five subcategories: chemicals excluding 
pharmaceuticals; electrical machinery and apparatus, n.e.c.; machinery and equipment, n.e.c.; motor vehicles, trailers and semi-trailers; railroad equipment and transport equipment, n.e.c.

Table 1: High-technology goods with respect to which Belarus recorded the highest comparative advantages (the highest RCA) in 2014

\begin{tabular}{|l|c|l|c|}
\hline No. & Category & \multicolumn{1}{|c|}{ Name } & $\begin{array}{c}\text { Value of the RCA } \\
\text { index }\end{array}$ \\
\hline 1. & HT & Telescopes for arms/other equipment, periscopes & 3.02 \\
\hline 2. & HT & Monoculars, telescopes, etc & 3.00 \\
\hline 3. & HT & Gas supply/production/calibration meters & 1.75 \\
\hline 4. & HT & Parts and accessories for binoculars, telescopes, etc & 1.50 \\
\hline 5. & HT & Instruments to measure or detect ionizing radiations & 1.48 \\
\hline 6. & HT & Binoculars & 1.25 \\
\hline 7. & HT & Parts and accessories of optical appliances nes & 1.17 \\
\hline 8. & HT & Parts and accessories for optical microscopes & 1.10 \\
\hline 9. & HT & Non-medical X-ray equipment & 1.06 \\
\hline 10. & HT & Spectacle lenses of glass & 0.45 \\
\hline \multicolumn{2}{l}{ Source: Author } \\
\hline
\end{tabular}

International competitiveness of Belarus in the subcategories mentioned above within the category of medium-high-technology goods is very differentiated (Figure 3). Belarus has by far the strongest comparative advantages in this category with respect to chemicals excluding pharmaceuticals. What's more, also in the subcategory of machinery and equipment, n.e.c. Belarus showed a certain level of international competitiveness, although over the years 2000-2014 the RCA index for this subcategory of goods was getting lower year by year, and in the years 2011-2012 and in 2014 was even negative. This, sadly, demonstrates the worsening competitive position of Belarusian economy in this area.

Figure 3: Dynamics of Revealed Comparative Advantages (RCA) in international trade of Belarus with respect to goods from the medium-high-technology category in the years 2000-2014

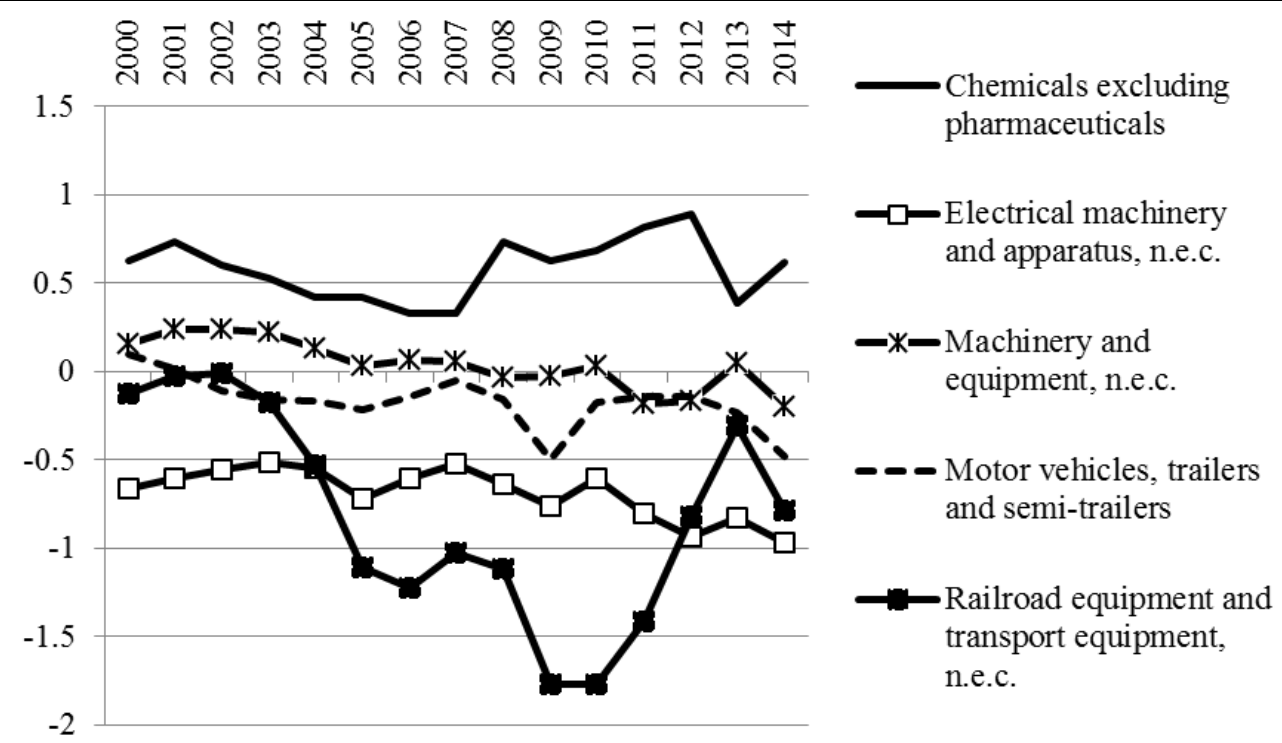

Source: Author

On the other end of the scale, the lowest competitiveness in international trade (the lowest value of the RCA indices) characterizes Belarus in the subcategories: electrical machinery and apparatus, n.e.c. and railroad equipment and transport equipment, n.e.c. In the case of the latter subcategory, a dramatic decline in the competitiveness of Belarusian economy occurred in the years 2002-2010. Even though in 2011-2013 some improvement was observed in this area, Belarus still did not record any comparative advantages, which proves that Belarusian railroad and transport equipment was not competitive in the international trade over the entire period. 
Table 2 below, in turn, presents the most internationally competitive Belarusian goods from the medium-high-technology category (with the highest values of the RCA index). It turns out that 6 out of 10 most competitive Belarusian goods from this category are from the subcategory of chemicals excluding pharmaceuticals.

Table 2: Medium-high-technology goods with respect to which Belarus recorded the highest comparative advantages (the highest RCA) in 2014

\begin{tabular}{|l|c|l|c|}
\hline No. & Category & \multicolumn{1}{|c|}{ Name } & $\begin{array}{c}\text { Value of the RCA } \\
\text { index }\end{array}$ \\
\hline 1. & MHT & Threshing machinery, n.e.c. & 5.39 \\
\hline 2. & MHT & Potassium chloride, in packs >10 kg & 4.71 \\
\hline 3. & MHT & Anti-knock preparations, except lead compounds & 4.55 \\
\hline 4. & MHT & Oil additives n.e.c., oxidation, corrosion, gum inhibitor & 3.92 \\
\hline 5. & MHT & Filament tow of acrylic or modacrylic & 3.89 \\
\hline 6. & MHT & Milling machines, knee-type n.e.c. for removing metal & 3.53 \\
\hline 7. & MHT & Diesel powered trucks weighing > 20 tonnes & 3.20 \\
\hline 8. & MHT & Liquid dielectric transformers < 650 KVA & 3.05 \\
\hline 9. & MHT & Urea-ammonium nitrate mixes in solution, pack >10 kg & 2.98 \\
\hline 10. & MHT & Hydrazine and hydroxylamine, inorganic salts & 2.93 \\
\hline \multicolumn{2}{|l|}{ Source: Author } & \\
\hline
\end{tabular}

Therefore, it is no surprise that it is in this subcategory that Belarus has traditionally been most competitive. Among the goods with the highest values of the RCA index in 2014 were also, amongst others, threshing machinery and milling machines, knee-type n.e.c. for removing metal from the machinery and equipment, n.e.c. subcategory.

\section{Conclusions}

The subject-matter of this study was an in-depth analysis of the international competitiveness of Belarus, with respect to the categories of goods of high and medium-high technology, conducted to assess the country's innovativeness and the effectiveness of its innovation policy.

The snapshot analysis, based on the assumption that the gauge of the innovativeness of Belarusian economy is its competitive position in international trade, has revealed that in the analyzed period of 2000-2014 Belarus was characterized by low innovativeness, as evidenced by a general lack of comparative advantages in the high-technology category overall. The situation was better in the case of goods from the medium-high technology category overall as Belarus did periodically possess some, although not high, comparative advantages in this regard. Of course, this does not mean that Belarus is not competitive in international trade concerning some goods from the high-technology or mediumhigh-technology category (according to the OECD classification), although such cases in the Belarusian foreign trade are sporadic. However, Belarus can compete internationally in respect of relatively low-tech (medium-low technology), low value-added, capital-intensive goods, coming basically from industries employing semi-skilled workers.

On the other hand, if we look at the results of the studies dynamically, i.e. analyzing the development of the RCA indices in the category of high- and medium-high-technology goods throughout the whole period of 2000-2014, as well as looking at the entire structure of Belarusian foreign trade (according to the OECD classification of goods based on their technological intensity), it turns out that generally Belarus' competitiveness deteriorated over that entire period. What are the reasons? Firstly, it is down to the low effectiveness of the innovation policy current pursued by Belarus, which is a direct consequence of, amongst others, the country's highly dysfunctional National Innovation System, its inability to use its relatively well-educated human resources in a pro-innovative way, low innovation awareness of Belarusian enterprises and the actual lack of policies supporting private innovation projects and start-ups. It is also the result of some serious structural weaknesses of the country's economic and socio-political system, which adversely affects its international investment attractiveness, and thus the possibility of improving the relatively low endogenous innovation capacity of Belarusian economy through know-how coming with foreign direct investments, as well as the efficiency of the entire economy. Secondly, the declining competitiveness of Belarus in international 
trade in goods of high technological intensity identified in this article is, to a large extent, also the effect of the increasing importance attributed to knowledge, technology, innovation, and consequently innovativeness in a growing number of countries of the contemporary globalized and dynamically changing world, in which high- and medium-high-technology goods are becoming more and more important. Thus, without implementing a feasible and consistent innovation policy, in the long run, Belarus will not be able to keep even these comparative advantages which it currently holds.

Based on the results of the analysis of Belarusian economy's competitiveness in international trade as evidenced by the presence of comparative advantages in the most innovative categories of goods, i.e. high-technology and medium-high-technology, the following general recommendations for Belarus can be formulated: 1) the country's pro-innovation potential should be used more pragmatically, especially in order to maintain the existing competitive advantages in the category of medium-lowtechnology goods, as well as to achieve sustainable advantages in international trade in medium-hightechnology and low-technology goods; 2) institutional conditions for doing business should be improved in order to effectively attract high-tech foreign investment creating spillover effects and increasing the innovativeness of Belarusian economy, which could translate into obtaining some competitive advantages in hi-tech goods; 3) workable innovation policy should be consistently implemented aimed to foster effective cooperation of state institutions, research centres and enterprises for the creation and commercialization of technologically advanced solutions. What's more, it seems that the effective execution of these recommendations will not be possible without the greater openness of Belarusian economy onto the world and without implementing structural economic reforms aimed to build a knowledge-based market economy. Undoubtedly, this will be a major challenge for Belarusian authorities; however, rising to it seems necessary in the rapidly growing, increasingly globalized world economy.

\section{References}

Aghion, P., \& Howitt, P. (1992). A Model of Growth through Creative Destruction. Econometrica, 60(2), 323-351.

Arrow, K. (1962). Economic Welfare and the Allocation of Resources for Invention. New York: Princeton University Press.

Atkinson, R. D., \& Ezell, S. J. (2012). Innovation Economics. The Race for Global Advantage. New Haven, London: Yale University Press.

Balassa, B. (1965). Trade liberalization and 'revealed' comparative advantage. The Manchester School of Economic and Social Studies, 33.

Balassa, B. (1989). 'Revealed' comparative advantage revisited. In B. Balassa (Ed.), Comparative advantage, trade policy and economic development. New York: New York University Press.

Bikár, M., \& Kmet'ko, M. (2015). The Economy Development in Countries Created the Euroasian Economic Union. International Journal of Science Commerce and Humanities, 3(2), 85-103.

Dabrowski, M. (2016). Belarus at a crossroads. Bruegel Policy Contribution, 2. Retrieved from http://bruegel.org/wpcontent/uploads/2016/01/pc_2016_02.pdf

Dobrinsky, R., Adarov, A., Bornukova, K., Havlik, P., Hunya, G., Kruk, D., \& Pindyuk, O. (2016). The Belarus Economy: The Challenges of Stalled Reforms. wiiw Research Report, 413, The Vienna Institute for International Economic Studies.

Drucker, P. (1992). Managing for the future. New York: Truman Talley/E.P. Dutton.

Dutta, S., Lanvin, B., \& Wunsch-Vincent, S. (Eds.). (2015). Global Innovation Index 2015. Effective Innovation Policies for Development, Geneva: World Intellectual Property Organization.

Egorov, A. (2014). Features of the Belarusian Economic Model. Retrieved from http://www.tstefaniuk.uph.edu.pl/zeszyty/archiwalne/101-2014_3.pdf.

European Union. (2014). Innovation Union Scoreboard 2014, Brussels: European Commission.

Falkowski, K. (2013). Międzynarodowa konkurencyjność gospodarek Białorusi, Rosji i Ukrainy [International Competitiveness of the Economies of Belarus, Russia and Ukraine], Warsaw: Warsaw School of Economics Press.

Falkowski, K. (2016). Skuteczność polityk innowacyjnych krajów Europy Wschodniej w kontekście poziomu konkurencyjności ich gospodarek w handlu międzynarodowym [The effectiveness of Eastern European countries' innovation policies with view to their economies' competitiveness in international trade]. International Business and Global Economy, 35(1), 295-308

Freinkman, L., Bakanova, M., \& Sidarenka, M. (2010). Belarus: Trade Performance and Competitiveness. Belarus Economic Policy Notes, 2. Retrieved from http://dx.doi.org/10.2139/ssrn.2410061

Hämäläinen, T. J. (2003). National Competitiveness and Economic Growth. The Changing Determinants of Economic Performance in the World Economy, Cheltenham: Edward Elgar.

Hatzichronoglou, T. (1997). Revision of the high technology sector and product classification. STI Working Papers 1997/2. OECD/GD 97(216). Paris: Organisation for Economic Co-operation and Development. 
Havlik, P., Astrová, V., \& Pindyuk, O. (2012). Trade Integration in the CIS: Alternate Options, Economic Effects and Policy Implications for Belarus, Kazakhstan, Russia and Ukraine. wiiw Research Report, 381, The Vienna Institute for International Economic Studies.

Lucas, R. E. (1988). On the Mechanics of Economic Development. Journal of Monetary Economics, 22, 3-42.

Lundvall, B. A. (1992). National Systems of Innovation: Towards a theory of innovation and interactive learning. London: Pinter.

Organisation for Economic Co-operation and Development. (2011). ISIC Rev. 3 Technology intensity definition. Classification of manufacturing industries into categories based on $R \& D$ intensities. Retrieved from http://www.oecd.org/sti/ind/48350231.pdf.

Romer, P. (1989). Human Capital and Growth: Theory and Evidence. NBER Working Paper, 3173.

Schwab, K. (Ed.). (2016). The Global Competitiveness Report 2016-2017, Geneva: World Economic Forum.

Shirov, A. A, Sabchishina, K. E., \& Potapenko, V. V. (2016). Development of the Belarusian Economy. Problems of Economic Transition, 58(6), 487-498.

Siggel, E. (2006). International Competitiveness and Comparative Advantage: A Survey and a Proposal for Measurement. Journal of Industry, Competitiveness and Trade, 6.

Stern, S., Porter, M. E., \& Furman, J. L. (2002). The determinants of national innovative capacity. Research Policy, 31.

Vollrath, T. (1991). A theoretical evaluation of alternative trade intensity measures of revealed comparative advantage. Review of World Economics, 127(2), 265-280. 